\title{
Characterisation of strains of Salmonella serotype Livingstone by multiple typing
}

\author{
PAMELA B. CRICHTON, D. C. OLD, ANN TAYLOR and SHELLEY C. RANKIN* \\ Department of Medical Microbiology, University of Dundee Medical School, Ninewells Hospital, Dundee \\ DD1 9SY and *Scottish Salmonella Reference Laboratory, Stobhill Hospital, Glasgow G21 3UW
}

\begin{abstract}
Isolates of Salmonella serotype Livingstone (6,7:d:1,w) from man, water and various animals and animal products in Canada, England, France, Israel and Scotland were examined for ribotype, biotype and plasmid profile. Analysis by these methods indicated that an epidemic strain of Livingstone of ribotype 1/biotype 8/plasmid-type 6 was responsible for the major upsurge of Livingstone infection that occurred in man in Tayside (Scotland) between 1989 and 1991; that type was also isolated from spring water, animal feed and poultry. Livingstone isolates of ribotype 1/biotype 8 with plasmid profiles other than type 6 were also present in Scotland, England and France at that same time. Among representative Livingstone isolates from England, a strain of ribotype 2/biotype 1 was predominant in man and poultry products between 1988 and 1992, although strains of other ribotypes $(1,3$ and 4$)$ were also present. Strains of ribotype 3 of different biotypes were obtained from poultry and animal feed sources in Canada. A strain of ribotype 5/biotype 3 caused human infections in Israel between 1968 and 1992. Ribotyping, biotyping and plasmid profile analysis used together have helped to trace the sources and extent of spread of human infections caused by Salmonella Livingstone.
\end{abstract}

\section{Introduction}

Since its first isolation in 1951 [1], Salmonella serotype Livingstone (antigenic formula 6,7:d:1,w) has usually been associated in the UK with isolations from food animals and animal feed products [2]. Poultry, in particular, is a frequent source of Salmonella Livingstone [3-5]; in contrast, Livingstone is isolated infrequently from man [6]. However, from 1989 to 1991 there was a dramatic increase in the number of isolations of Livingstone from cases of human salmonellosis in the Tayside region of Scotland [7,8]; only serotype Enteritidis was isolated more often from Tayside patients. In the later stages of the Tayside outbreak, Livingstone spread northwards into the Grampian region in Scotland, but there was no similar upsurge in the incidence of Livingstone infection in man elsewhere in the UK [8].

For common serotypes of Salmonella - such as Enteritidis, Typhimurium and Hadar - phage typing used alone, or together with biotyping, has demon-

Received 1 Aug. 1995; accepted 13 Sept. 1995.

Corresponding author: Dr P.B. Crichton. strated the spillover of particular strains from animals to man [9-11]. However, because serotype Livingstone had been isolated so infrequently from man in the UK before 1989, no phage-typing scheme was available with which to investigate the spread of Livingstone or to distinguish the isolates from Tayside and elsewhere in Scotland. A combination of phenotypic and genotypic typing methods was used to demonstrate that the upsurge in human infection by Livingstone in Tayside was caused by an epidemic strain and to highlight the prevalence and possible sources of human infection with that and other Livingstone strains in the UK and elsewhere.

\section{Materials and methods}

\section{Bacteria}

The sources and donors of 167 Salmonella Livingstone cultures, isolated between 1968 and 1993, are listed in Table 1. The 114 Livingstone strains from Scotland (1985-1993) comprised: 50 isolated in the Department of Medical Microbiology, Ninewells Hospital and Medical School, Dundee, Tayside, from specimens, mainly of faeces, from different patients [8]; a further 15 from patients and nursing staff 
Table 1. Country of origin, donor, number and sources of isolates of Salmonella Livingstone

\begin{tabular}{|c|c|c|c|}
\hline$\frac{\text { Country }}{\text { Scotland }}$ & Donor & \multicolumn{2}{|r|}{ Number and source of isolates } \\
\hline Scotland & Dr D. C. Old & $\begin{array}{l}50 \\
15\end{array}$ & $\begin{array}{l}\text { Faeces and/or blood from Tayside patients } \\
\text { Faeces from patients (14) and nurse (1) in hospital } \\
\text { outbreak in North Tayside }\end{array}$ \\
\hline & $\begin{array}{l}\text { Mr D. S. Munro, Scottish Salmonella Reference } \\
\text { Laboratory, Stobhill Hospital, Glasgow }\end{array}$ & 35 & Faeces from patients in areas other than Tayside \\
\hline & & 4 & $\begin{array}{l}\text { Faeces from patients returned from Spain (2), } \\
\text { Minorca (1) and Portugal (1) }\end{array}$ \\
\hline & & 1 & Spring water \\
\hline & & 9 & Poultry \\
\hline Canada & $\begin{array}{l}\text { Dr C. Poppe, Agriculture Canada, Health Animals } \\
\text { Laboratory, Guelph, Ontario }\end{array}$ & 3 & $\begin{array}{l}\text { Poultry faeces or environment dust (2), hog } \\
\text { supplement (1) }\end{array}$ \\
\hline England & $\begin{array}{l}\text { Dr B. Rowe, Laboratory of Enteric Pathogens, Central } \\
\text { Public Health Laboratory, London }\end{array}$ & 26 & $\begin{array}{l}\text { Human faeces (10), poultry ( } 7) \text {, egg }(7) \text {, and other } \\
\text { animal products }(2)\end{array}$ \\
\hline & Dr C. Wray, Central Veterinary Laboratory, Weybridge & 3 & Animal feed \\
\hline France & $\begin{array}{l}\text { Dr M. Y. Popoff, WHO Collaborating Center for } \\
\text { Reference and Research on Salmonella, Unite des } \\
\text { Entérobactéries, Institut Pasteur, Paris }\end{array}$ & 9 & $\begin{array}{l}\text { Human faeces (3), dried or fresh egg (2), water (1), } \\
\text { poultry (1), delicatessen (1), reference strain from } \\
\text { human stool in Great Britain (1) }\end{array}$ \\
\hline Israel & $\begin{array}{l}\text { Dr I. Sechter, Ministry of Health, Government Central } \\
\text { Laboratories, Jerusalem }\end{array}$ & 12 & $\begin{array}{l}\text { Human faeces (5), animal feed (1), unknown sources } \\
\text { (4), pet meal from USA (1), residue meal from } \\
\text { England (1) }\end{array}$ \\
\hline
\end{tabular}

involved in a hospital outbreak in North Tayside in 1990 [8]; 39 from patients in other parts of Scotland, including four who had recently returned from mainland Spain, Minorca or Portugal; one from water and nine isolated from poultry in 1990-1991. These isolates have been described previously $[7,8,12]$. Another 53 isolates were obtained from Canada, England, France and Israel (Table 1).

Isolates were stored at room temperature $\left(c .18-20^{\circ} \mathrm{C}\right)$ on Dorset's egg slopes until subcultured on Columbia Blood Agar Base (Oxoid) containing defibrinated horse blood $5 \% \mathrm{v} / \mathrm{v}$.

The serotype name Livingstone designates Salmonella with the antigenic formula $6,7: \mathrm{d}: 1, \mathrm{w}$ [13]. Isolates from sources other than the Scottish Salmonella Reference Laboratory (SSRL), PHLS Laboratory of Enteric Pathogens (LEP) and The Central Veterinary Laboratory (CVL) were serotyped at SSRL and $\underline{\mathrm{O}} 14^{+}$ variants of serotype Livingstone $(6,7, \underline{14}: \mathrm{d}: 1, \mathrm{w})$, formerly designated as Salmonella serotype Eimsbuettel [13], were excluded from this study.

\section{Substrates tested for their ability to distinguish different biotypes among 167 isolates of Salmonella Livingstone}

Isolates were examined for the production of gas from glucose and for the ability to ferment 27 carbohydrates (adonitol, D-amygdalin, L-arabinose, L-arabitol, arbutin, D-cellobiose, 2-deoxy-D-galactose, 2deoxy-D-glucose, dulcitol, D-fructose, L-fucose, Dgalactose, myo-inositol, D-lyxose, maltose, D-mannose, D-melezitose, O-methyl- $\alpha$-D-glucose, D-raffinose, Lrhamnose, D-ribose, D-sorbitol, L-sorbose, D-trehalose, xylitol, D-xylose and L-xylose) when tested in either or both 4-ml and 200- $\mu 1$ volumes of Peptone Water (Oxoid) $1.5 \% \mathrm{w} / \mathrm{v}$ containing carbohydrate $0.5 \% \mathrm{w} / \mathrm{v}$ and bromocresol purple $0.002 \% \mathrm{w} / \mathrm{v}$ as $\mathrm{pH}$ indicator in 5 -ml bottles [14] or microtitration plates [15]. The ability to ferment these carbohydrates on eosinmethylene blue agar [16] and to utilise them as sole carbon and energy source in minimal salts agar [17] was tested on 9-cm plates and in microwells. Isolates were also tested, by previously detailed methods, for utilisation of D- and L-tartaric acids $[14,18]$ and production of aldehyde from glycerol in Stern's medium [14].

\section{Plasmid profile analysis of 167 isolates of Salmonella Livingstone}

Plasmid DNA was examined in crude lysates prepared by a modification of the method of Platt and Sommerville [19]. Bacterial growth from a nutrientagar plate incubated overnight in air at $37^{\circ} \mathrm{C}$ was harvested in $600 \mu$ l of Tris-borate-EDTA (TBE) buffer [20] in a $1.5-\mathrm{ml}$ microfuge tube. SDS $10 \% \mathrm{w} / \mathrm{v}$ in TBE was added $(300 \mu l)$ with gentle mixing. Lysis was achieved within $10 \mathrm{~min}$ at $50^{\circ} \mathrm{C}$. After centrifugation at $13000 \mathrm{~g}$ for $10 \mathrm{~min}$, the pellet was discarded and the lysate, which contained the plasmid DNA in open circular configuration, was examined immediately or stored at $4^{\circ} \mathrm{C}$ for $\leqslant 1$ week.

Plasmids were separated by electrophoresis of the lysate through a vertical $10 \times 15-\mathrm{cm}$ gel containing SeaKem GTG agarose (Flowgen, Sittingbourne, Kent) $0.7 \% \mathrm{w} / \mathrm{v}$ in TBE buffer at $100 \mathrm{~V}$ for $1 \mathrm{~h}$ followed by $3 \mathrm{~h}$ at $200 \mathrm{~V}$. After electrophoresis, the gel was stained in ethidium bromide $6 \mu \mathrm{g} / \mathrm{ml}$, examined under UV light $(312 \mathrm{~nm})$ and photographed on Polaroid 665 film. The mol.wt of large plasmids was determined with reference to plasmids of known size $(\mathrm{kb})$ - Rts 1 (180), RA-1 (127), R1 (93), R702 (69) and RP4 (54) prepared by the same method; that of small plasmids $(<16 \mathrm{~kb})$ was estimated by comparison with the 
Supercoiled DNA Ladder (Life Technologies, Paisley). Mol. wts were determined on at least two occasions.

\section{Extraction of cellular DNA from 110 isolates of Salmonella Livingstone}

Isolates from which DNA was extracted for ribotyping included all those from England, France, Israel and Canada (53) and 57 from Scotland. The latter included representative isolates from each of the years 1985 to 1993 and others with plasmid profiles different from the majority type 6: from Dundee patients (25); from patients in other parts of Scotland, including four recently returned from abroad (18); from spring water (1); from the hospital outbreak (4); and from poultry (9).

For DNA extraction, isolates were inoculated in $\mathrm{L}$ broth [21] $(10 \mathrm{ml})$ in $20-\mathrm{ml}$ sterile disposable plastic screwcapped, V-bottomed tubes $(2 \times 9 \mathrm{~cm})$ and shaken overnight $(100 \mathrm{rpm})$ at $37^{\circ} \mathrm{C}$. Extraction of cellular DNA was performed by a modification of Silhavy's method [22]. Briefly, bacterial cells frozen in $0.4 \mathrm{ml}$ of buffer (50 mM Tris, $50 \mathrm{mM}$ EDTA, pH 8.0) in microfuge tubes were thawed in the presence of lysozyme $1 \mathrm{mg} / \mathrm{ml}$ and placed on ice for $45 \mathrm{~min}$. Freshly prepared STEP solution (SDS $0.5 \% \mathrm{w} / \mathrm{v}, 50 \mathrm{mM}$ Tris- $\mathrm{HCl}, 0.4 \mathrm{M}$ EDTA, pH 7.5, containing Proteinase $\mathrm{K} 1 \mathrm{mg} / \mathrm{ml}) 80 \mu \mathrm{l}$ was added and tubes were incubated at $50^{\circ} \mathrm{C}$ for $1 \mathrm{~h}$ with occasional mixing. After chilling on ice, cell suspensions were extracted twice with equilibrated phenol and DNA was precipitated with 0.1 volumes of $3 \mathrm{M}$ sodium acetate $(\mathrm{pH} 6.0)$ and two volumes of cold $\left(-20^{\circ} \mathrm{C}\right)$ ethanol. Precipitated DNA was transferred with a sterile pipette tip to a fresh tube containing $0.4 \mathrm{ml}$ of TE buffer $(50 \mathrm{mM}$ Tris- $\mathrm{HCl}, 1 \mathrm{M}$ EDTA, $\mathrm{pH}$ 7.5). The dissolved DNA was extracted once with chloroform, precipitated as above, washed in ethanol $70 \% \mathrm{w} / \mathrm{v}$, centrifuged to pellet, dried under vacuum and dissolved in TE buffer.

\section{Preparation of the ribosomal RNA gene probe}

Escherichia coli LL1048 containing plasmid pT711 was provided by Professor L. Lindahl, Department of Biology, University of Rochester, Rochester, NY, USA. The DNA probe of $E$. coli ribosomal RNA was the 3.8-kb Pvu II restriction fragment of pT711 which contained the $r r n B 16 \mathrm{~S}$ gene, the glutamate tRNA2 gene and the promotor-proximal half of the 23S gene [23]. Probe DNA (25 ng), purified by previously described methods [24], was labelled with deoxycytiden $5^{\prime}-\left[\alpha_{-}^{32} \mathrm{P}\right]$-triphosphate by the Multiprime system (Amersham International).

\section{Southern hybridisations}

Cellular DNA (2- $\mu$ g amounts) was digested in $20-\mu \mathrm{l}$ volumes with EcoRI (Promega, Southampton). Restriction fragments were separated by electrophoresis at ambient temperature in agarose gels (type 1: low EEO, Sigma) $0.9 \% \mathrm{w} / \mathrm{v}$ containing ethidium bromide $0.5 \mu \mathrm{g} / \mathrm{ml}$ in TBE buffer. DNA was denatured in $1.5 \mathrm{M}$ $\mathrm{NaCl}$ containing $0.5 \mathrm{M} \mathrm{NaOH}$ for $30 \mathrm{~min}$ and transferred by capillary blotting to Hybond-N membranes (Amersham) with alkali buffer $(0.25 \mathrm{M} \mathrm{NaOH}, 1.5 \mathrm{M}$ $\mathrm{NaCl}$ ). Membrane hybridisations and washes were carried out at $65^{\circ} \mathrm{C}$ as described previously $[24,25]$. The bound probe was visualised after exposure of the membrane to Hyperfilm (Amersham) for $1-6 \mathrm{~h}$ at $-70^{\circ} \mathrm{C}$ and development of the film in a Dupont Cronex T-6 Processor. Fragment sizes were calculated with reference to those of the 1-kb DNA ladder (Life Technologies).

\section{Results}

Biochemical tests for differentiation of strains of serotype Livingstone

All 167 isolates of Salmonella Livingstone, tested as described above, produced gas from glucose fermentation and gave consistent results in fermentation and utilisation tests with the following substrates: all positive for L-arabinose, dulcitol, D-fructose, L-fucose, D-galactose, maltose, D-mannose, L-rhamnose, Dribose, D-sorbitol, D-trehalose, D-xylose; all negative for adonitol, D-amygdalin, L-arabitol, arbutin, Dcellobiose, 2-deoxy-D-galactose, 2-deoxy-D-glucose, O-methyl- $\alpha$-D-glucose, myo-inositol, D-lyxose, D-melezitose, D-raffinose, L-sorbose, xylitol and L-xylose. Thus, these tests provided no strain discrimination.

However, when the 167 isolates were tested for utilisation of D- and L-tartaric acids and metabolism of glycerol in Stern's medium, 37 utilised d-tartaric acid, 28 utilised L-tartaric acid and 42 formed aldehyde from glycerol in Stern's medium. Results were reproducible on different occasions of testing. Thus, these three tests reliably distinguished seven of eight potential biotypes of Livingstone (Table 2). All but one of the 114 isolates from Scotland belonged to biotype 8 (negative in all three tests), which corresponds to biotype 2 (D- and L-tartaric acid not utilised) of Odongo et al. [2].

\section{Plasmid profile analysis of 167 isolates of Salmonella Livingstone}

Of the 114 Scottish isolates, 90 from patients and one from spring water carried a single plasmid of $6.5 \mathrm{~kb}$, as estimated by the method outlined above. That same plasmid was estimated in its supercoiled configuration to be of $1.8 \mathrm{MDa}$, i.e., the cultures belonged to plasmid-type 6 according to the CVL nomenclature [12]. Two Scottish poultry isolates carried that same plasmid. Eighteen isolates from man were plasmid free (including four from patients recently returned from Spain, Minorca and Portugal); one human isolate carried two plasmids (6.5 kb and smaller) and two 
poultry isolates carried single plasmids of $3.6 \mathrm{~kb}$ or $5.4 \mathrm{~kb}$ (Table 3 ). The $6.5-\mathrm{kb}$ plasmid was also present in the three isolates from animal feed received from CVL, England [12].
Among the 53 isolates from diverse sources in countries other than Scotland, 18 different plasmid profiles were detected and 24 isolates were plasmid free (Table 3).

Table 2. Biotypes and test reactions with Salmonella Livingstone cultures obtained from different countries and sources

\begin{tabular}{|c|c|c|c|c|}
\hline \multirow[b]{2}{*}{ Biotype } & \multicolumn{3}{|c|}{ Reaction in test with } & \multirow[b]{2}{*}{ Country of origin (sources) and number of cultures } \\
\hline & D-tartrate & L-tartrate & Stern's glycerol & \\
\hline 1 & + & + & + & England (man, chicken, egg, meal, crate scraps) 20 ; France (egg) 1 \\
\hline 2 & + & + & - & Scotland (poultry) 1 \\
\hline 3 & + & - & + & $\begin{array}{l}\text { Canada (turkey litter) 1; England (man, chicken, fermented meat) 3; France } \\
\text { (man, egg powder) 2; Israel (man, unkown) 8; USA (pet meal) 1 }\end{array}$ \\
\hline 4 & + & - & - & 0 \\
\hline 5 & - & + & + & Canada (hen faeces) 1; England (man, chicken) 3; Israel (unknown) 1 \\
\hline 6 & - & + & - & Canada (pig feed supplement) 1 \\
\hline 7 & - & - & + & Israel (unknown) 1 \\
\hline 8 & - & - & - & $\begin{array}{l}\text { Scotland (man, poultry, spring water) } 113 \text {; England (man, chicken, animal } \\
\text { feed) 5; France (man, delicatessen, poultry, water) } 5\end{array}$ \\
\hline
\end{tabular}

Table 3. Source, ribotype, biotype and plasmid profile of 110 isolates of Salmonella Livingstone

\begin{tabular}{|c|c|c|c|c|c|}
\hline Number of cultures & Country & Source & Ribotype & Biotype & Plasmids (kb) \\
\hline 22 & Scotland & Man (Dundee) & 1 & 8 & 6.5 \\
\hline 3 & & Man (Dundee) & 1 & 8 & 0 \\
\hline 9 & & Man; water & 1 & 8 & 6.5 \\
\hline 1 & & Man & 1 & 8 & $6.5:<6.5$ \\
\hline 4 & & Man & 1 & 8 & 0 \\
\hline 4 & & Man (abroad) & 1 & 8 & 0 \\
\hline 4 & & Man (hospital outbreak) & 1 & 8 & 6.5 \\
\hline 1 & & Man (hospital outbreak) & 1 & 8 & 0 \\
\hline 2 & & Poultry & 1 & 8 & 6.5 \\
\hline 5 & & Poultry & 1 & 8 & 0 \\
\hline 1 & & Poultry & 1 & 8 & 5.4 \\
\hline 1 & & Poultry & 1 & 2 & 3.6 \\
\hline 1 & Canada & Hen faeces & 3 & 5 & 0 \\
\hline 1 & & Turkey litter & 3 & 3 & 0 \\
\hline 1 & & Pig feed supplement & 3 & 6 & 0 \\
\hline 3 & England & Man; chicken; fermented meat & 1 & 3 & 0 \\
\hline 3 & & Animal feed & 1 & 8 & 6.5 \\
\hline 9 & & Man; egg; crate scraps & 2 & 1 & 0 \\
\hline 1 & & Chicken & 2 & 1 & 70 \\
\hline 5 & & Chicken; egg & 2 & 1 & 35 \\
\hline 1 & & Powdered egg & 2 & 1 & 7 \\
\hline 1 & & Egg & 2 & 1 & 7.2 \\
\hline 1 & & Man & 2 & 1 & 80 \\
\hline 1 & & Man & 1 & 8 & 0 \\
\hline 1 & & Chicken & 1 & 8 & 4 \\
\hline 1 & & Chicken & 3 & 5 & 160: 7 \\
\hline 1 & & Chicken & 3 & 5 & $90: 7$ \\
\hline 1 & & Man & 4 & 5 & 90 \\
\hline 3 & France & Man; delicatessen & 1 & 8 & $8: 4.5$ \\
\hline 2 & & Poultry; water & 1 & 8 & 4.5 \\
\hline 1 & & Man & 1 & 3 & 2.5 \\
\hline 1 & & Powdered egg & 1 & 3 & 0 \\
\hline 1 & & $\begin{array}{l}\text { Man (reference strain from Great } \\
\text { Britain) }\end{array}$ & 2 & 1 & 0 \\
\hline 1 & & Egg & 2 & 1 & 0 \\
\hline 1 & Israel & Animal feed & 1 & 7 & 0 \\
\hline 1 & & Unknown & 3 & 5 & 0 \\
\hline 2 & & Man & 5 & 3 & 200: $10: 8: 2.5$ \\
\hline 2 & & Man; unknown & 5 & 3 & 200: $10: 8$ \\
\hline 1 & & Man & 5 & 3 & $\begin{array}{c}150: 10: 8: 6: \\
2.5\end{array}$ \\
\hline 1 & & Man & 5 & 3 & 150: $10: 8: 2.5$ \\
\hline 1 & & Unknown & 5 & 3 & 8 \\
\hline 1 & & Unknown & 1 & 3 & 0 \\
\hline 1 & & Pet meal (USA) & 5 & 3 & 0 \\
\hline 1 & & Residue meal (UK) & 2 & 1 & 0 \\
\hline
\end{tabular}






Fig. 1. Autoradiograph showing ribotypes of Salmonella Livingstone. Lanes $1-5$, ribotypes $1-5$, respectively; 6, mol. wt markers (kb).

\section{Ribotypes of Salmonella Livingstone}

Among the 110 isolates that were chosen to represent different years of isolation, biotypes, plasmid types, countries and animal sources, five different ribotype patterns were observed (Fig. 1).

All of the 57 Scottish isolates examined (from water, poultry and man, and including the four from patients who had recently returned from Spain, Minorca or Portugal) belonged to ribotype 1, in which 11 EcoRI DNA fragments hybridised with the probe (Fig. 1, lane 1). A further 17 isolates of ribotype 1 from man, poultry, animal feed and other sources (Table 3) were received from donors in England (eight), France (seven) and Israel (two). Twenty-one isolates of ribotype 2 (Fig. 1, lane 2) from England (18), France (two) and Israel (one) were from man, egg or other animal sources. Six isolates of ribotype 3 (Fig. 1, lane 3) were from poultry and animal feed in Canada (three), England (two) and Israel (one); ribotype 4 (Fig. 1, lane 4), a variant of ribotype 3 lacking the $c$. 2-kb hybridised band, was shown by an isolate from a patient in England; eight isolates from Israel, includ- ing one originally obtained from American pet meal, belonged to ribotype 5 (Fig. 1, lane 5). Thus, ribotyping showed all Scottish isolates to be related and identified different groups among isolates from other countries and diverse sources.

\section{Discrimination of Salmonella Livingstone strains by combined typing methods}

The results obtained when the 110 isolates described above were analysed by multiple typing methods are detailed in Table 3.

It is clear that Salmonella Livingstone of ribotype 1/ biotype 8 was an important cause of infection in man, especially in Tayside, Scotland, between 1985 and 1991: one isolate from a patient in 1993 also belonged to that type as did most (eight of nine) isolates from Scottish poultry (Table 3). The majority (82\%) of Scottish isolates carried a $6.5-\mathrm{kb}$ plasmid (plasmidtype 6, see ref. [12]). Of the few plasmid-free isolates, most were from patients who had recently returned from abroad or who lived in areas of Scotland outwith Tayside.

Livingstone strains of ribotype 1/biotype 8 were also isolated from animal and human sources in England and France. However, only the three animal feed isolates from CVL belonged to plasmid-type 6; others, isolated from various sources between 1990 and 1991, showed different plasmid profiles (Table 3).

Isolates of ribotype 2 were generally from human, egg or poultry sources and mostly from England (but including two cultures received from France and Israel, Table 1); they were invariably of biotype 1 (Table 3). Livingstone isolates of ribotype 2 showed various plasmid profiles (Table 3); plasmid-free isolates were obtained from egg and man. Isolates of ribotype 3 from poultry and animal feed showed different plasmid profiles and biotypes (Table 2). No human isolate was available for comparison.

Eight isolates of ribotype 5 belonged to biotype 3 and included three serotyped as rough:d:1,w. The same large plasmids of $150 \mathrm{~kb}$ or $200 \mathrm{~kb}$, as determined by restriction endonuclease digest analysis, were present in both smooth and rough ( $\mathrm{O}$ untypable) isolates.

\section{Discussion}

It is probable that the area over which any new Salmonella strain spreads locally or nationally reflects the extent of distribution of a contaminated food or animal feed. However, it was difficult to explain the dramatic emergence in Tayside, and not elsewhere in the UK, of Salmonella Livingstone as the serotype second in importance only to Enteritidis in 1989 and 1990. In spite of exhaustive epidemiological studies at 
that time, no food vehicle was identified for cases of human salmonellosis either in the community or associated with a hospital outbreak $[7,8]$. Furthermore, there had been no recent isolations of Livingstone from food animals in Scotland. The subsequent fall in incidence of human infections with Livingstone was as dramatic as its rise: after September 1991 there were very few human cases in Tayside.

Typing methods for the differentiation of Salmonella strains enable associations to be made between human cases of salmonellosis as well as between cases and food vehicles, food animals or geographical areas. However, even serotyping, which defines over 2000 different types of Salmonella, is rarely sufficient for that purpose. The superimposition of results of additional typing techniques on serotyping helps to detect subtle differences among strains causing disease in the same or different areas.

As might have been expected from previous knowledge of the epidemiology of Livingstone [4,5], typing profiles of poultry isolates received in the laboratory after the outbreak showed that poultry or poultry products were a possible source of the human infections in Tayside and other parts of Scotland; two of nine Scottish poultry isolates had the same ribotype, biotype and plasmid profile as isolates from patients. Interestingly, three English isolates from animal feed were identical by all three typing methods, which suggested that contaminated poultry feed had provided the vehicle of entry for Salmonella Livingstone into the human food chain.

Although biotyping used alone does not usually provide a good measure of strain relatedness among different isolates of Salmonella, the combined use of biotyping (with 15 characters) and phage typing has proved to be a useful epidemiological tool for revealing associations in the short term among isolates of Salmonella serotypes Typhimurium [10] and Paratyphi B [26]. Despite the fact that only three (D- and L-tartaric acid and Stern's glycerol), of 31 substrates tested in this study provided any biotype discrimination among Livingstone strains, biotypes 1 and 8 were stable indicators of the English and Scottish epidemic strains during several years.

An important disadvantage of plasmid analysis as a typing tool is that it is limited to strains that contain plasmids and that these plasmids may, by nature, be unstable or mobile. Provided that these limitations are recognised, the overall typing pattern resulting from the combined use of ribotyping, biotyping and plasmid profile analysis is powerful enough to enable minor variations, such as the loss or acquisition of a single plasmid as seen in this study, to be discounted. However, the majority of Scottish isolates contained the same $6.5-\mathrm{kb}$ plasmid, which confirmed their relatedness and indicated poultry as the likely source of human illness.

All three Livingstone isolates from animal feed or poultry in Canada were of ribotype 3 , although minor differences in the number of weakly hybridised bands between 3 and $5 \mathrm{~kb}$ were observed (data not shown); they also showed differences in biotype (see Table 3). Only two other isolates of ribotype 3 were identified, both from English poultry sources. Although their plasmid profiles were different, both were of biotype 5 and carried an identical 7-kb plasmid, suggesting a common source.

French isolates of Livingstone were mainly of ribotype 1/biotype 8 but, unlike Scottish isolates, were of plasmid types other than type 6; common plasmids were those of 4.5 and $8 \mathrm{~kb}$ which were present in isolates from water, poultry, a delicatessen source and man. Ribotype 2/biotype 1, the profile of the British reference strain received from France, was found in an isolate from an egg in France indicating, again, that poultry products were the source of human infection.

In Israel, Salmonella Livingstone has caused infrequent human infection (Dr I. Sechter, personal communication). However, five human isolates obtained in 1969 and 1970 were related, as indicated by their ribotype 5/biotype 3 and plasmid profiles. No isolates were available from poultry but a plasmid-free isolate of the same ribotype and biotype was obtained from North American pet meal.

Of the 26 isolates received from LEP, the majority (18) belonged to ribotype 2/biotype 1 and, thus, were clearly different from the predominant Scottish strain; 10 of the isolates from England were from poultry or eggs and seven from man. Thus, again, a link was demonstrated between poultry and human infection. It is interesting that ribotype 3 , as in Canada, was isolated from poultry but not from man. It is possible that Livingstone with that typing profile has a higher infective dose; alternatively, the poultry may be sold for human consumption in a manner different from the poultry contaminated with the Scottish epidemic strain.

The highly efficient modern poultry industry provides a valuable, inexpensive source of protein for human consumption. However, the intensive living and processing conditions result in a high proportion of the birds becoming contaminated with salmonellae that may cause human infection which is low in mortality but, nevertheless, has important social and economic consequences. The results of multiple typing have highlighted the importance of poultry as a vehicle for human salmonellosis and have indicated that contaminated animal feedstuff is a likely source of Salmonella serotype Livingstone. 
We acknowledge with gratitude the gift of cultures of Salmonella Livingstone from Mr D. S. Munro, Dr C. Poppe, Dr B. Rowe, Dr C. Wray, Dr M. Y. Popoff and Dr I. Sechter. We thank Mr H. Mather for serotyping strains and $\mathrm{Mr}$ G. Wilson for help with biochemical testing.

\section{References}

1. Picton WHA, Stirrup W, Price A, Taylor J. A new salmonella type (Salm. livingstone). J Pathol Bacteriol 1953; 66: 310-312.

2. Odongo MO, McLaren IM, Smith JE, Wray C. A biotyping scheme for Salmonella livingstone. Br Vet $J$ 1990; 146: 75-79.

3. Ministry of Agriculture, Fisheries and Food. Salmonella in animal and poultry production 1992. CVL, Addlestone, UK. 1993: $1-40$.

4. Reilly WJ, Oboegbulem SI, Munro DS, Forbes GI. The epidemiological relationship between Salmonella isolated from poultry meat and sewage effluents at a long-stay hospital. Epidemiol Infect 1991; 106: 1-10.

5. Oboegbulem SI. Poultry meat and human salmonellosis: establishing the epidemiological relationship. $\mathrm{PhD}$ thesis, University of Glasgow. 1990.

6. Reilly WJ, Forbes GI, Sharp JCM, Oboegbulem SI, Collier PW, Paterson GM. Poultry-borne salmonellosis in Scotland. Epidemiol Infect 1988; 101: 115-122.

7. Old DC, Porter-Boveri M, Munro DS. Recent emergence of Salmonella of serotype Livingstone in and around Dundee. Communicable Diseases (Scotland) Weekly Report 1990; 34: 6-10.

8. Old DC, Porter-Boveri M, Munro DS. Human infection in Tayside, Scotland due to Salmonella serotype Livingstone. J Med Microbiol 1994; 40: 134-140.

9. Ward LR, de Sa JDH, Rowe B. A phage-typing scheme for Salmonella enteritidis. Epidemiol Infect 1987; 99: 291-294.

10. Old DC, Barker RM. Persistent and transient clones of Salmonella typhimurium of phage type 141 recognized by biotyping. Epidemiol Infect 1989; 102: 113-118.

11. de Sa JDH, Ward LR, Rowe B. A scheme for the phage typing of Salmonella hadar. FEMS Microbiol Lett 1980; 9: 175-177.

12. Old DC, McLaren IM, Wray C. A possible association between Salmonella Livingstone strains from man and poultry in Scotland. Vet Rec 1995; 137: 544.
13. Popoff MY, Le Minor L. [Antigenic formulas of the Salmonella serovars, 6th revision.] WHO Collaborating Center for Reference and Research on Salmonella. Paris, Institut Pasteur. 1992.

14. Duguid JP, Anderson ES, Alfredsson GA, Barker R, Old DC. A new biotyping scheme for Salmonella typhimurium and its phylogenetic significance. J Med Microbiol 1975; 8: 149-166.

15. Crichton PB, Logan JMJ, Old DC. A miniaturized biotyping system for strain discrimination in Escherichia coli. Epidemiol Infect 1993; 111: 81-88.

16. Meynell GG, Meynell E. Theory and practice in experimental bacteriology. Cambridge, Cambridge University Press. 1965: 36-37.

17. Davis BD, Mingioli ES. Mutants of Escherichia coli requiring methionine or vitamin B12. J Bacteriol 1950; 60: 17-28.

18. Alfredsson GA, Barker RM, Old DC, Duguid JP. Use of tartaric acid isomers and citric acid in the biotyping of Salmonella typhimurium. J Hyg 1972; 70: 651-666.

19. Platt DJ, Sommerville JS. A simple method for the detection of resistance plasmids in Serratia species by transfer to members of the genus Enterobacter. $J$ Antimicrob Chemother 1981; 8: 145-152.

20. Sambrook J, Fritsch EF, Maniatis T. Molecular cloning. A laboratory manual, 2nd edn, vol 1. Cold Spring Harbor, NY, Cold Spring Harbor Laboratory. 1989: 6.7.

21. Miller JH. Experiments in molecular genetics. Cold Spring Harbor, NY, Cold Spring Harbor Laboratory. 1972: 433.

22. Silhavy TJ, Berman ML, Enquist LW. Experiments with gene fusions. Cold Spring Harbor, NY, Cold Spring Harbor Laboratory. 1984: 137-139.

23. Selander RK, Beltran P, Smith NH et al. Evolutionary genetic relationships of clones of Salmonella serovars that cause human typhoid and other enteric fevers. Infect Immun 1990; 58: 2262-2275.

24. Crichton PB, Old DC. Salmonellae of serotypes Gallinarum and Pullorum grouped by biotyping and fimbrial-gene probing. $J$ Med Microbiol 1990; 32: 145-152.

25. Crichton PB, Anderson LA, Phillips G, Davey PG, Rowley DI. Subspecies discrimination of staphylococci from revision arthroplasties by ribotyping. $J$ Hosp Infect 1995; 30: 139-147.

26. Barker RM, Kearney GM, Nicholson P, Blair AL, Porter RC, Crichton PB. Types of Salmonella paratyphi $B$ and their phylogenetic significance. J Med Microbiol 1988; 26: 285-293. 